\title{
Kemoterapotik ajan olarak dosetakselin ARH 77 Ig G plazma hücreli lösemi hücre serisi üzerindeki sitotoksik etkisi
}

\author{
The cytotoxic effect of docetaxel on Ig G plasma cell leukemia cell line ARH-77 \\ as a chemotherapeutic agent
}

\author{
Zehra Dilşad Çoban, Ferit Avcu, Ali Uğur Ural, Şefik Güran* \\ Tıbbi Biyoloji Anabilim Dalı (Dr. Z. D. Çoban, Prof. Dr. Ş. Güran), Gülhane Askeri Tıp \\ Akademisi, TR-06010 Ankara, (Prof. Dr. F. Avcu, Prof. Dr. A. U. Ural), Gülhane Askeri Tip \\ Akademisi, Sağlık Bilimleri Enstitüsü Araştırma ve Geliştirme Merkezi, TR-06018 Ankara
}

\begin{abstract}
Özet
Amaç. Dosetaksel, hücrede mitotik iğciğin oluşum aşamasında mikrotübül stabilizasyonuna neden olarak hücre bölünmesini durdurup hücrenin apopitozise gidişini sağlar. Dosetaksel meme, prostat ve mesane kanserinde sık kullanılan bir ilaçtır. Çalışmada Ig G plazma hücreli lösemi örneği olan hücre hattı [ARH-77 ATCC No: CRL-1621] üzerinde başka birçok kanserin tedavisinde ilaç olarak kullanılan dosetaksel ile ortaya çıkabilecek sitotoksik etki araştırıldı. Yöntem. Çalışmada ARH-77 hücreleri üzerinde 0,1-1-10-50-100 umol/L olacak şekilde farklı dosetaksel konsantrasyonları kullanılarak sitotoksik etki incelendi. Sitotoksik etki XTT testi ile değerlendirildi. Bulgular. İnsan Ig G plazma hücreli lösemi örneğini oluşturan ARH-77 hücre hattında dosetakselin artan konsantrasyonlarında oluşturduğu sitotoksik etki ortaya kondu. Sonuç. Veriler dosetakselin 50 umol konsantrasyonunda ARH-77 hücreleri üzerinde letal doza eriştiğini göstermiştir. Dosetakselin plazma hücreli lösemi hücre hattında etkin sitotoksik etkisi bu ilacın nadir gözlenen ve kötü prognozla karakterize hastalık tedavisinde kullanılabileceğini düşündürmektedir. Fakat bu ilacın plazma hücreli lösemide kullanımı için daha ileri testlere ihtiyaç vardir.
\end{abstract}

Anahtar sözcükler: Dosetaksel, ARH-77, mitoz inhibisyonu, plazma hücreli lösemi, sitotoksik etki

\begin{abstract}
Aim.: Docetaxel causes microtubule stabilization during mitotic spindle organizing in cell and forces the cell to go apoptosis. Docetaxel is widely used in breast, prostate and bladder cancer. The potential cytotoxic effect of docetaxel, a chemotherapeutic agent which is used in various cancers, on Ig G plasma cell leukemia cell line (ARH-77- ATCC No: CRL-1621) was investigated in this study. Methods. The cytotoxic effect of docetaxel on ARH-77 cell line was evaluated at different concentrations namely 0.1-1-10-50-100 umol/L by using XTTtest. Result. It was shown that, docetaxel had significant cytotoxic affect at higher concentrations on ARH-77 cell line which forms a sample of human Ig G plasma cell leukemia. Conclusion. The data represent that the lethal dose of docetaxel in ARH-77 cell line is at the concentration of $50 \mathrm{umol} / \mathrm{L}$. Our results suggest that docetaxel could be useful in the treatment of plasma cell leukemia of rare cases associated with poor prognosis. But further tests are needed to use this drug in plasma cell leukemia.
\end{abstract}

Keywords: Docetaxel, ARH-77, mitotic catastrophe, plasma cell leukemia, cytotoxic effect

Geliş tarihi/Received: 24 Ağustos 2011; Kabul tarihi/Accepted: 14 Haziran 2012

*İletişim adresi:

Dr. Şefik Güran, Tıbbi Biyoloji Anabilim Dalı, Gülhane Askeri Tıp Akademisi, TR-06010

Ankara. E-posta: sefguran@yahoo.com 


\section{Giriș}

Ig G plazma hücreli lösemi lenfoproliferatif hastalıklar içinde yer alan plazma hücre kökenli bir malignitedir. Çok nadir gözlenir. Plazma hücresinden köken alan hastalıkların \%2-4'ünü oluşturur. Hastalık tüm kanserler içinde en agresif seyreden gruptadır. Olguların \%60-70'i primer olarak ortaya çıkar. Sekonder grup içinde çoğunlukla multiple myelomdan transforme olan form vardır. Bir anlamda hastalı multiple myelomun ileri terminal formudur. Tedavide başta siklofosfamid, doksorubisin, vinkristin ve prednizon olmak üzere farklı ilaçlar tek ve kombine olarak kullanılmaktadır. Tüm farklı tedavi yaklaşımlara rağmen ortalama sağ kalım süresi 18-20 aydır [1, 2]. Dosetaksel, taksanlar grubundan mikrotübül stabilize edici bir ajandır. Mitozda önemli olan tübülin molekülüne yüksek afinite ile bağlanır. Böylece mitoz gerçekleşemez. Proliferasyon durur ve hücre apopitoza gider [3]. Hem in vitro hem de in vivo çalışmalarda hücre içine alımının hızlı olmasına bağlı olarak dosetakselin bir çok hücre grubunda anti-neoplastik aktivite gösterdiği bulunmuştur [4, 5]. Dosetakselin farklı sitotoksik ajanla kombine edilebileceğini destekleyen yayınlar mevcuttur [6].

Çalışmamızda halen plazma hücreli lösemi protokolünde bulunmayan ancak sistemik etkisi nedeni ile plazma hücreli lösemi üzerinde etkili olabileceğini düşündügümüz dosetaksel, farklı konsantrasyonlarda hazırlanarak Ig G plazma hücreli lösemi hücre hattı (ARH-77-ATCC-No: CRL-1621) üzerinde denenmiştir. Dosetakselin, ARH-77 hücre hatt1 üzerine olan sitotoksik etkisi kolorometrik bir test olan XTT testi ile değerlendirilmiş ve elde edilen veriler istatistiksel olarak değerlendirilmiştir [7].

\section{Gereç ve yöntem}

\section{Dosetaksel konsantrasyonlarının hazırlanması}

Dosetaksel (Doxel®Mustafa Nevzat İlaç) Morse ve ark.' nın protokolüne uyularak RPMI 1640 (Sigma-Aldrich-R8758) içinde çözülmüş ve 0,1-1-10-50-100 umol/L olacak şekilde farklı konsantrasyonlarda hazırlanmıştır [3].

\section{Hücre kültürü}

Bu çalışmada Ig G plazma hücreli lösemi hücre hattı (ARH-77- ATCC No: CRL-1621) kullanılmıştır. Hücreler \% 10(v/v) fetal bovin serum (BiochromAG, Germany) ve \%1(v/v) penisilin-streptomisin (Biological Industries, Israel) içeren RPMI 1640 (Sigma-AldrichR8758) içine alınmış, $37^{\circ} \mathrm{C}$ 'de, $\% 5 \mathrm{CO}_{2}$ 'li ortamda (Heraeus inkübatörü-Hanau, Germany) çoğaltılmıştır [8]. Hücre kültürü sonrası sayıları artan hücreler XTT Assay (Cell Proliferation Kit, Biological Industries, Israel) için her kuyucukta 1x $10^{6}$ hücre olacak şekilde 96 kuyucuklu plağa yerleştirilmiştir. Hücrelerin yapışma ve çoğalması için etüvde $37^{\circ} \mathrm{C}$ 'de 24 saat bekletilmiştir. Tablo 1'de belirtilen konsantrasyonlardaki ilaç derişimleri 24 saatin sonunda hücreler üzerine ilave edilmiştir. Her deney grubunda kontrol grubu olarak sadece medyum ve medyum ile hücrelerin oluşturduğu gruplar kullanılmıştır. Çalışmada ilaç eklenen grupla, ilaç eklenmeyen kontrol grubundan elde edilen sonuçlar karşılaştırılmıştır (Tablo 1).

Tablo 1. Dosetakselin 96'lık well-plate' te ARH-77 hücre hattı üzerine uygulanması

\begin{tabular}{llll}
\hline Blank & Kontrol & Deney 1 & Zaman \\
\hline$M$ & M+ARH-77 & ARH-77+D-0,1 & 24 SAAT \\
$M$ & M+ARH-77 & ARH-77+D-1 & 24 SAAT \\
M & M+ARH-77 & ARH-77+D-10 & 24 SAAT \\
$M$ & M+ARH-77 & ARH-77+D-50 & 24 SAAT \\
$M$ & M+ARH-77 & ARH-77+D-100 & 24 SAAT \\
\hline
\end{tabular}

M: Medyum (RPMI 1640)

ARH-77: Plazma hücreli lösemi hücre hattı (Human plasma cell leukemia cell line)

ATCC No: CRL 1621

D: Dosetaksel 


\section{XTT (Cell Proliferation Assay Kit) testi}

ARH-77 hücre hattının ilaç uygulamasından sonra oluşturduğu sitotoksititeyi ölçmek için XTT (2, 3-bis (2-methoxy-4-nitro-5-sulfophenyl)-5-[(phenylamino)carbonyl)]-2Htetrazolium ydroxide) uygulamasında üretici firmanın protokolü ile Mutlu ve ark. [9] uygulamaları esas alınmıştır. İlaç uygulamasından 24 saat sonra 96 kuyucuklu deney plağına XTT solusyonu eklenerek, $490 \mathrm{~nm}$ dalga boyunda mikroplate okuyucusundaokutularak her deney grubunda bulunan hücrelerin canlıl1kları analiz edilmiştir. Böylece çalışma sonucunda 24. saatteki yaşayan hücreler ile ölü hücrelerin yüzdelerini elde ettiğimiz hücre canlılığını gösteren XTT çıtılları elde edilmiştir. Çalışmada altılı tekrar grupları kullanılmıştır. Dosetakselin artan konsantrasyonlarda ARH-77 hücre hattında oluşturduğu sitotoksik etkisi Şekil 1'de gösterilmiştir. In vitro hücre kültür çalışmalarında ilaç etkinliği inhibitör konsantrasyon 50 (IC 50) değeri ile bulunmuştur.

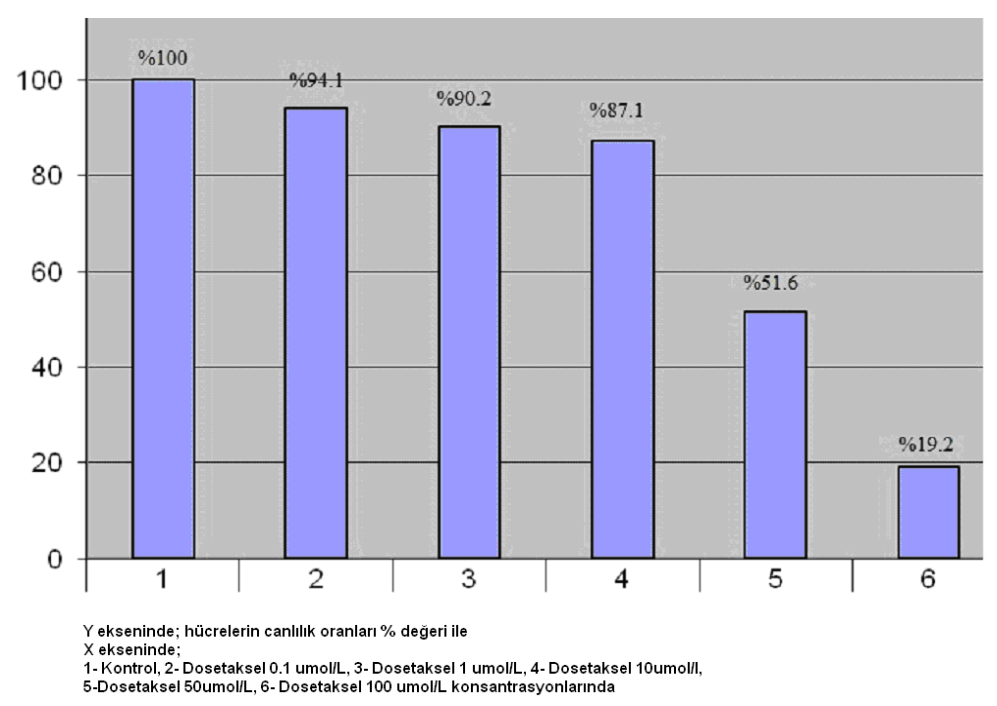

Şekil 1. Dosetakselin artan dozlarda ARH-77 (human plasma cell leukemia) hücre hattında oluşturduğu sitotoksik etki.

\section{İstatistiksel analiz}

Tüm istatistiksel analiz ve hesaplamalar için MS-Excel 2003 ve "SPSS for Windows Ver. 15.0" (SPSS Inc., Chicago, IL., USA) paket programları ile ANOVA analizi kullanıldı. İstatistiksel kararlarda (Bonferroni düzeltmesi yapılan analizler hariç) $\mathrm{p}<0,05$ düzeyi anlamlı farklılı̆̆ın göstergesi olarak kabul edildi.

\section{Bulgular}

Çalışmamızda dosetakselin artan konsantrasyonlarda ARH-77 (Ig G plazma hücreli lösemi) hücre hattında oluşturduğu sitotoksik etki Şekil 1'de gösterilmiştir. Buna göre ilk üç grup arasında kontrol grubuna göre anlamlı farklılık olmamasına rağmen $(\mathrm{p}>0,05)$ son iki deney grubunda kontrol grubuna göre anlamlı farklılık olduğu gözlemlenmiştir $(\mathrm{p}<0,05)$.

Çalışmada XTT assay için kontrol grubu olarak kullanılan medya ve ARH-77 hücrelerinin bulunduğu kuyucukların ortalama değeri 0,781 iken 50 um/l konsantrasyonunda dosetaksel uygulanan kuyucukların ortalama değeri 0,403 olarak gözlemlenmiştir.

Bilindiği gibi IC50 değeri hücrelerin \%50' sini öldüren toksik konsantrasyon olarak tanımlanmaktadır. Çalışmamızda Şekil 1'de görüldüğü üzere kontrol grubunu takiben dosetakselin artan konsantrasyonlarda hücrelerin canlılık yüzdeleri giderek azalmış ve 50 umol/L konsantrasyonunda canlıl1k \%51 seviyelerine inmiştir. Son konsantrasyon olan 
100 umol/L konsantrasyonunda ise canlılık \%19' lara düşmüştür. Burada 50 umol/L ile 100 umol/L konsantrasyonları arasında bulunan bir değer hücrelerin \%50'sini öldüren konsantrasyon olarak değerlendirilmiştir. Burada elde edilen veriler ışığında dosetakselin 24 saat sonundaki IC50 değeri hesaplanarak 52,47 umol/L olduğu bulunmuştur.

\section{Tartışma}

Dosetaksel taksan grubunda yer alan sistemik etkili bir ilaçtır. Uzun y1llardır kemoteropotik olarak kullanılmakta olup, birçok kanser türünde etkisi bilinmektedir. Çok nadir gözlenen ve kötü prognoza sahip bir kanser türü olan Ig G plazma hücreli lösemi için bu ilacın kullanımı ile ilgili kapsamlı bir çalışma bulunmamaktadır [10]. Kanser olgularında ilaç yanıtı bu ilaçların etki mekanizmasına, uygulama dozlarına olduğu kadar kullanılan hücrelerin köken aldığı dokuya, kanser hücresinin özelliklerine ve onların genetik değişikliklerine bağlıdır [3]. Dosetaksel, hücrelerde mitotik iğciğin oluşumunda görevli mikrotübülleri bloke ederek hücre bölünmesini engellemektedir. Hücre çoğalmas1 engellenen tümör hücreleri apopitozise gitmektedir [11]. Günümüzde dosetaksel özellikle metastaik meme kanseri, prostat, mesane, over, mide ve küçük hücreli akciğer kanserinde kullanılmaktadır [4]. Bu olgularda cerrahi öncesi ve sonrası kullanımı yönünde önemli çalışmalar vardır [12-14]. Ancak burada sistemik yan etkileri önemli bir sorun olarak halen güncelliğini korumaktadır Bazı ileri evre kanser olgularında dosetakselin tek başına kullanımı yetersiz kalabilmektedir [15].

Plazma hücreli lösemi plazma hücrelerinden kaynaklanan nadir görülen agresif bir neoplastik bozukluktur [16]. Plazma hücreli lösemi primer olarak ortaya çıkabildiği gibi bir diğer plazma hücre diskrazisi olan multipl myelomaya sekonder olarak da görülebilir. Her iki malignitede de bulgular aynıdır ancak plazma hücreli lösemide beklenen yaşam süresi aylarla ölçülür. Plazma hücreli lösemi patogenezinde yer alan mekanizmalar tam olarak açıklanamamakta ve plazma hücrelerinin neden kemik iliğinden dışarı çıkıp agresif metaztaz özelliği kazandığı bilinmemektedir [2]. Çok çeşitli tedavi yöntemleri denenmiş olmasına rağmen plazma hücreli lösemi tanısı almış hastalarda tam tedavi mümkün olmamakta, beklenen yaşam süresi 7-11 ayı geçmemektedir [1].

Çalışmamızda, hücrede mitotik süreçte oluşan mikrotübül oluşumunu stabilize ederek hücrenin proliferasyonunu durduran ve hücrenin apopitozise gidişine sebep olan dosetakselin ARH-77 plazma hücreli lösemi hücre hatt1 üzerindeki etkisini inceledik. Hücre hatları üzerine uygulanan ilaçlara verilen yanıt sadece ilaç konsantrasyonuna ya da ilacın etki mekanizmasına değil aynı zamanda hücrenin yapısal ve genetik özelliklerine bağlıdır [3]. ARH-77 hücre hattı agresif seyreden ve sağ kalım oranlarının düşük olduğu bir lösemi türü olan plazma hücreli lösemiye ait hücrelerden meydana gelmiştir. Metastaz oranı yüksek olması sebebiyle bu kanserde öncelikli olarak metastazın önlenmesini sağlayan tedavi protokollerinin kullanılması uygundur [16]. Bu sebeple dosetakselin kombinasyon tedavileri ile birlikte kullanılması tedaviye alınan cevabın başarısını etkileyecektir. Normalde plazma hücreli lösemi tedavi protokolünde yer almayan dosetakselin ARH-77 hücre hatt1 üzerindeki sitotoksik etkisi belirgindir (Tablo 1). Bu durum gerek tek başına gerekse kombinasyon tedavilerinde dosetakselin plazma hücreli lösemi tedavisinde kullanım alanı bulabileceği fikrini desteklemektedir. Dosetakselin sistemik etkilerinin yanında yan etki profilinin de ilacın kullanım alanını kısıtladığı göz önüne alındığında dosetaksel ile kullanılabilecek farklı ilaç kombinasyonlarının bulunması önem kazanmaktadır.

Sonuç olarak her ilaç geliştirme çalışmasında olduğu gibi dosetakselin etkin dozunun bulunması ve olası yan etkilerinin ortaya konabilmesi için başta başka plazma hücreli lösemi hücre hatları ve hayvan deneyleri olmak üzere ileri deneylere ihtiyaç vardır [15]. Birçok çalışmada ortaya konduğu gibi bu ilacın farklı ilaç kombinasyonlarında denemesinin de önemli olabileceği değerlendirilmektedir $[9,17]$. 


\section{Kaynaklar}

1. Albarracin F, Fonseca R. Plasma cell leukemia. Blood Rev 2011; 25: 107-12.

2. Sher T, Miller KC, Deeb G, Lee K, Chanan-Khan A. Plasma cell leukaemia and other aggressive plasma cell malignancies. Br J Haematol 2010; 150: 418-27.

3. Morse DL, Gray H, Payne CM, Gillies RJ. Docetaxel induces cell death through mitotic catastrophe in human breast cancer cells. Mol Cancer Ther 2005; 4: 1495504.

4. Lyseng-Williamson KA, Fenton C. Docetaxel: a review of its use in metastatic breast cancer. Drugs 2005; 65: 2513-31.

5. Karampeazis A, Vamvakas L, Agelidou A, Kentepozidis N, Chainis K, Chandrinos V, Vardakis N, Pallis AG, Christophyllakis C, Georgoulias V. Docetaxel vs. vinorelbine in elderly patients with advanced non-small-cell lung cancer: a hellenic oncology research group randomized phase III study. Clin Lung Cancer 2011; 12: 155-60.

6. Gregory WM, Richards MA, Malpas JS. Combination chemotherapy versus melphalan and prednisolone in the treatment of multiple myeloma: an overview of published trials. J Clin Oncol 1992; 10: 334-42.

7. Scudiero DA, Shoemaker RH, Paull KD, Monks A, Tierney S, Nofziger TH, Currens MJ, Seniff D, Boyd MR. Evaluation of a soluble tetrazolium/formazan assay for cell growth and drug sensitivity in culture using human and other tumor cell lines. Cancer Res 1988; 48: 4827-33.

8. Dönmez Y, Gündüz U. Reversal of multidrug resistance by small interfering RNA (siRNA) in doxorubicin-resistant MCF-7 breast cancer cells. Biomedicine \&Pharmacotherapy 2011; 65: 85-9.

9. Mutlu P, Baran Y, Ural AU, Avcu F, Dirican B, Beyzadeoglu M, Gündüz U. Effect of cobalt-60 ( $\gamma$ radiation) on multidrug-resistant multiple myeloma cell lines. Cell Biology Int 2011; 35: 721-5.

10. Clarke SJ, Rivory LP. Clinical pharmacokinetics of docetaxel. Clin Pharmacokinet 1999; 36: 99-114.

11. Morgan C, Lewis PD, Jones RM, Bertelli G, Thomas GA, Leonard RC. The in vitro anti-tumour activity of zoledronic acid and docetaxel at clinically achievable concentrations in prostate cancer. Acta Oncol 2007; 46: 669-77.

12. Fury MG, Pfister DG. Current Recommendations for Systemic Therapy of Recurrent and/or Metastatic Head and Neck Squamous Cell Cancer. J Natl Compr Canc Netw 2011; 9: 681-9.

13. Grimer R, Judson I, Peake D, Seddon B. Guidelines for the management of soft tissue sarcomas. Sarcoma 2010; 2010: 506182.

14. Fabbri F, Amadori D, Carloni S, Brigliadori G, Tesei A, Ulivi P, Rosetti M, Vannini I, Arienti C, Zoli W, Silvestrini R. Mitotic catastrophe and apoptosis induced by docetaxel in hormone-refractory prostate cancer cells. J Cell Physiol 2008; 217: 494-501.

15. Cortes JE, Pazdur R. Dosetaxel. J Clin Oncol 1995; 13: 2643-55.

16. Jimenez-Zepeda VH, Dominguez-Martinez VJ. Plasma cell leukemia: a highly aggressive monoclonal gammopathy with a very poor prognosis. Int J Hematol 2009; 89: 259-68.

17. Uysal Y, Ural AU, Avcu F, Güngör S, Hürmeriç V, Erdem Ü, Durukan AK, Bayer A, Bayraktar MZ. Meme kanseri (MCF-7) ve Burkitt lenfoma (Raji) hücre dizileri üzerine in vitro ortamda hiperisin ile fotodinamik tedavi araştırma sonuçları. Gülhane Tıp Dergisi 2007; 49: 147-52. 